\title{
On the Problems and Countermeasures of Agricultural Trade and Anti-poverty under the Pattern of High Quality Development
}

\author{
Hui Li
}

School of Economics and Management, Zhejiang Ocean University, Zhoushan 316022, Zhejiang, China

\begin{abstract}
With the rapid economic development and strong policy support, the targets and tasks of poverty alleviation are completed on schedule, but the foundation of anti-poverty areas is not solid and the internal motivation is insufficient. At the same time, China's agricultural trade liberalization has also penetrated in all aspects of economy, employment and society. This paper explains the current situation in detail and analyzes the relationship between agricultural trade liberalization and the prevention of return to poverty, and what strategies should be made at this stage to prevent the return to poverty at this stage.
\end{abstract}

Keywords: Agricultural products trade liberalization, Anti-poverty and double-cycle rural development.

\section{Purpose and Significance of the Research}

During the 13th Five-Year Plan period, rural revitalization has opened up a good situation and achieved a decisive victory in poverty alleviation. The 14th Five-Year Plan period is a critical period for comprehensively promoting rural revitalization and accelerating agricultural and rural modernization. Now international forces play with each other. China is rich in labor resources, abundant and low labor force make Chinese labor-intensive industries have a place on the world map with low price advantage. On the basis of trade and investment protectionism and economic and trade frictions, China's external trade environment has changed and the international external cycle suffers resistance[1]. Under the policies on agriculture, rural areas and farmers, the production level and efficiency of agriculture have begun to be greatly improved, the industrial structure and industrial allocation have been more reasonable, and agricultural products have begun to develop in the direction of more liberalization and diversification.

Trade liberalization of agricultural products is an important influence of the rapid growth of agricultural economy, and the rapid growth of agricultural economy is the main factor to improve the income of rural population. Theoretically speaking, farmers' income and trade liberalization of agricultural products are somewhat related, which can be analyzed in terms of price structure and industrial structure and income structure. Price mechanism: price mechanism regulates agricultural price and market resources, price mechanism can allocate agricultural production, investment direction and scale, thus control price and affect the distribution of national income; industrial structure: vigorously import products difficult to produce, export profitable products popular in the world market; rural income structure of the rural population will change accordingly[2].

By analyzing and studying the relationship between trade liberalization of agricultural products and anti-poverty, we can see whether it can lead rural people to prevent the return to poverty, and whether it has a positive impact on rural anti-poverty as predicted. Further promote the technical adjustment and renewal of agricultural products industry, improve the employment rate; according to national policy support to the development of rural economy according to improving the quality of labor human capital for agricultural trade; and finally provide relevant opinions according to the results.

\section{Influence Factors of Trade Liberalization of Agricultural Products on Anti-poverty}

\subsection{Economic Growth}

There is a positive relationship between foreign trade and economic growth, and in the process of development, as the degree of free trade in agricultural products becomes deeper and deeper. Figure 1 shows the annual changes in the per capita disposable income of the rural Chinese residents.

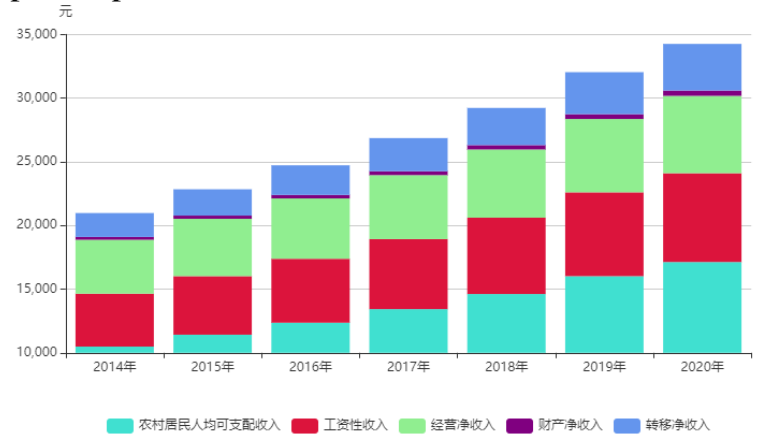

Figure 1: Annual changes in the per capita disposable income of Chinese rural residents from 2014-2020

Data source: Ministry of Agriculture and Rural Affairs, People's Republic of China

It can be seen from Figure 1 that if we want to raise the farmers' income level and economic conditions, it is not enough to rely only on the government policies, financial subsidies and the protection policies of agricultural products. Therefore, we can increase wage income and household business income through agricultural trade liberalization, and fundamentally lead farmers to get rid of poverty and become rich. To be specific: we can plant local superior agricultural 
products in a certain area, and then increase the investment in science and technology within a certain range, so that it can become a series of large-scale agricultural industrial chains, and form a stable industrial production mode. In this way, it not only increases the wage income and family operating income, but also further expands the production mode and diversified development of agricultural products trade[3].

\subsection{State Policy}

Today, with the deepening opening up of agricultural trade, the Chinese government, while paying attention to international trade, will still pay attention to whether rural residents can gain benefits from it and seek more conducive to rural poverty growth under the sky of the liberalization of agricultural trade. In 2021, in order to comprehensively prevent the return to poverty, China has introduced a series of policies to benefit farmers and poverty alleviation, improve the happiness index of rural living standards, and encouraged aspiring young people in the country to go to the grassroots, participate in the daily work of rural areas, and put forward support projects conducive to the region according to the specific situation[4].

\subsection{Employment Situation}

The trade in agricultural products affects farmers' employment through economic growth. More reasonable agricultural products trade policies can not only promote the enthusiasm of farmers to change their production mode, but also improve their employment situation. Agricultural products trade through agricultural industrial structure upgrading and further rationalization to improve the rural employment rate and improve rural employment situation, through the optimization of agricultural production technology and agricultural production pattern, according to the principle of comparative advantages, China can to the international market like and large demand of superior resources of a large number of export, with this part of the economic property to improve the efficiency of agricultural products production and the level of science and technology. Further upgrading of the industrial structure will maximize the advantages of China's labor force to the greatest extent, so as to improve the difficult employment problem and low employment rate in some areas of China[5].

Table 1 shows that the number of rural employed workers in China has increased from 761.05 million to 774.71 million, The reason why the proportion of rural employment and employment personnel have flat or even decreased in recent years is: first, due to the change in age structure, China's population development has also taken a turning point, The working population aged 16-59 declined, And the rural population began to move to cities and towns, The total rural population is also declining; second, China's agricultural products export is more and more concentrated in labor-intensive fruits and vegetables, That does increase jobs, but as competitive pressure on agricultural exports grows, China has increased the labor productivity of agricultural products, In recent years, the employment rate has grown slowly or even flat in recent years.

Table 1: Number of employees at the end of 2010-2019

\begin{tabular}{|c|c|c|c|}
\hline \multicolumn{4}{|c|}{ Number of Employed Persons at Year-end in Urban and Rural Areas } \\
\hline $\begin{array}{l}\text { Unit: ten } \\
\text { thousand } \\
\text { people, } \%\end{array}$ & & & (10 000 persons, $\%)$ \\
\hline \multirow[b]{2}{*}{ Year } & $\begin{array}{l}\text { Employment } \\
\text { personnel }\end{array}$ & \multicolumn{2}{|c|}{ Country Rural } \\
\hline & $\begin{array}{c}\text { Total Number of } \\
\text { Employed } \\
\text { Persons }\end{array}$ & \begin{tabular}{|c|} 
Employment \\
personnel \\
Employed Persons
\end{tabular} & $\begin{array}{c}\text { Share of employment } \\
\text { in the primary industry } \\
\text { Proportion }\end{array}$ \\
\hline 2010 & 76105 & 41418 & 67.4 \\
\hline 2011 & 76420 & 40506 & 65.7 \\
\hline 2012 & 76704 & 39602 & 65.1 \\
\hline 2013 & 76977 & 38737 & 62.4 \\
\hline 2014 & 77253 & 37943 & 60.1 \\
\hline 2015 & 77451 & 37041 & 59.2 \\
\hline 2016 & 77603 & 36175 & 59.4 \\
\hline 2017 & 77640 & 35178 & 59.5 \\
\hline 2018 & 77586 & 34167 & 59.3 \\
\hline 2019 & 77471 & 33224 & 59.2 \\
\hline
\end{tabular}

Data source: China Rural Statistical Yearbook 2020

\section{Empirical Analysis of Agricultural Products Trade Liberalization and Rural Poverty Alleviation Status Quo}

\subsection{Building of the Model}

We in terms of economic growth, and national policy and employment in three aspects, the main factor to prevent rural poverty is economic growth, by exploring the relationship between total import and export and rural economic GDP to further explore, so we use economeometry, establish the total import and export and China's rural economic GDP return equation to analyze, the model is as follows:

$$
\ln Y=\beta_{0}+\beta_{1} \ln X
$$

In this equation, $X$ is the total import and export of agricultural products, and $Y$ is the gross rural economy. $\beta_{0} \beta_{1}$ To estimate the parameters. We analyzed the data on the total import and export trade of agricultural products and the total GDP of rural economy.

\subsection{Variable Assumptions and Data Sources}

In order to empirical analyze the import and export of agricultural products, it is necessary to select the two groups of the total import and export of agricultural products and China's rural economic GDP. Because the total trade of agricultural products represents the situation of China's import and export of agricultural products, and the gross domestic rural economy represents the development level of China's rural economy, the data from 2010 to 2020 are selected for analysis and test.

\subsubsection{Variable hypothesis}

The larger the scale of China's import and export trade of agricultural products, the larger the rural economic GDP, the 
positive relationship between the two will grow, which will play a positive role in preventing the problem of rural returning to poverty.

\subsubsection{Data source}

The total import and export of agricultural products trade comes from the collection of China Financial and Economic Network, and China's rural economic GDP comes from the National Bureau of Statistics.

Table 2: Total rural economic GDP and total import and export trade of agricultural products

\begin{tabular}{|c|c|c|}
\hline Time & $\begin{array}{l}\text { Gross rural economic } \\
\text { product (100 million yuan) }\end{array}$ & $\begin{array}{c}\text { Total import and export trade of } \\
\text { agricultural products (RMB) (RMB } \\
100 \text { million) }\end{array}$ \\
\hline In 2010 & 38430.8 & 8615.13 \\
\hline 2011 & 44781.4 & 10992.84 \\
\hline 2012 & 49084.5 & 12416.21 \\
\hline 2013 & 53028.1 & 13187.59 \\
\hline 2014 & 55626.3 & 13620.61 \\
\hline 2015 & 57774.6 & 13249.05 \\
\hline 2016 & 60139.2 & 13037.13 \\
\hline 2017 & 62099.5 & 14225.98 \\
\hline 2018 & 64734.0 & 15315.24 \\
\hline 2019 & 70473.6 & 15644.76 \\
\hline In 2020 & 77754.1 & 16784.44 \\
\hline
\end{tabular}

Data source: The National Bureau of Statistics

\subsection{Empirical Analysis}

\subsubsection{Scatter plot analysis}

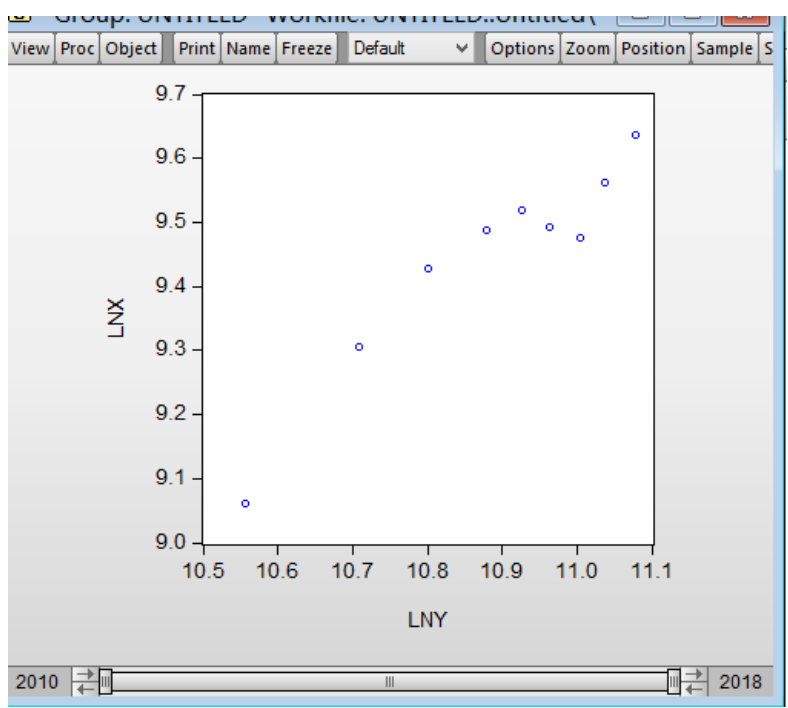

Figure 2: Scatter plot model

Figure 2 is the distribution of scatter plots generated by the Eviews 10.0 software, and it is clear from the graph showing the positive relationship of $\ln Y$ with $\ln X$.

\subsubsection{Correlation analysis}

Using Eviews10.0 software for regression analysis, the least squares regression equation is:

$$
\ln Y=1.8968+0.95196 \ln X
$$

The measurement results showed $R^{2}=0.905721$, greater than 0.9 indicating good fit and $\mathrm{P}$ value less than 0.05 is significant; $\mathrm{DW}=1.843845$ with positive correlation. The larger the total trade in agricultural products, the larger the rural economic GDP, the positive relationship between the two, that is, the trade liberalization of agricultural products can prevent the return to poverty.

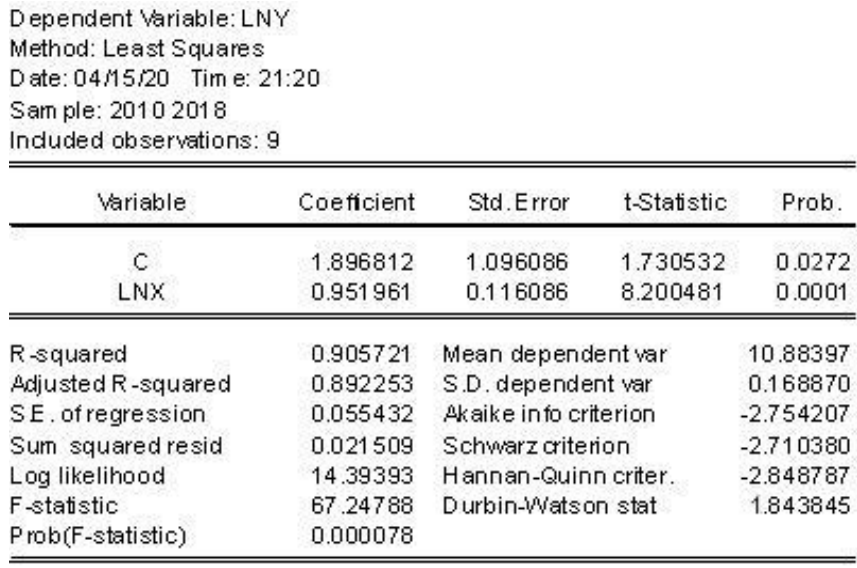

Figure 3: Results of the regression analysis

\section{Conclusion}

Through data analysis: the liberalization of agricultural trade and rural poverty in China; with the difference of labor skills and national development strategy, the effect of agricultural trade liberalization on the prevention of poverty.

To sum up, from a macro level, the liberalization of agricultural trade has promoted poverty alleviation in rural China, but there are certain differences in the impact on different regions and different development directions. From the micro level, the liberalization of agricultural trade has improved the quality of employment, but the employment efficiency can not be greatly improved in the short term. Similarly, for the labor force, the impact of trade liberalization of agricultural products on them is also different, because their technical level and knowledge conservation are different, so the degree of making their families out of poverty is different. The national policy began to vigorously promote targeted poverty alleviation from all aspects and further support the development of trade liberalization in agricultural products.

\section{Policy Suggestions}

\subsection{Pay Attention to the Improvement of the Quality of the Labor Force}

Now the rapid development of Chinese science and technology information, so the quality of labor is very important, only the quality of labor, can use technology and developed modern information to better develop agricultural trade liberalization, higher education level and quality can faster drive economic growth and employment, lead the rural poor people out of poverty. In terms of this aspect, the scientific and technological literacy and technological improvement of the labor force are particularly important. Only by constantly improving their educational knowledge level can we quickly integrate into the modern fast-paced knowledge learning process quickly. This requires not only 
the government to increase the education for workers, but also the workers themselves to make reasonable use of social educational resources. At the same time, we should attach great attention to the proportion of educational resources in various places, reduce the uneven distribution of educational resources, actively cultivate a large number of young talents and young talents who go out to learn a wider range of high-tech knowledge, and increase the quantity and quality of talents in China[6].

\subsection{Support Nongovernmental Forces in Strengthening the Liberalization of Trade in Agricultural Products}

First of all, we should actively encourage and guide the flexible flow of our labor force between different regions, and form a trend of employment. At the same time, we should also carry out the labor transfer training, so as to greatly improve the quality and knowledge level of farmers. Through social forces to promote more and more rural farmers to share the benefits and opportunities of China's economic development, with this method to prevent the income gap in different regions from further increasing. At the same time to further improve the domestic market construction system and mechanism, improve and strengthen our country market intermediary organization, to eliminate the market gap between urban and rural areas, is conducive to domestic agricultural trade liberalization to consolidate and improve the infrastructure, only to further meet the needs of agricultural import and export trade, our economy may be pulled up.

\subsection{Strengthen the Trade Liberalization of Agricultural Products under the New Pattern of Double-cycle Development}

We should take the domestic cycle as the main body, expand internal demand and focus consumer demand in expanding internal demand. In order to promote the development of our domestic and international double circulation economy, we must first enhance and consolidate China's status in the world pattern, improve the quality of domestic and foreign circulation under the double circulation pattern, and further promote high-level opening up to the outside world.

\section{References}

[1] Wang Jing. Study on Comparative Advantage of Chinese Agricultural Products and Its Impact Factors [D]. Central China Agricultural University, 2014.

[2] Wang Chunguang. Setting of Rural Poverty Problems and Continuation of Anti-poverty Practice in China [J]. Research on Social Development, 2020, 7(03): 15-27.

[3] Zhao Deyu. Circular feedback mechanism of poverty trap and anti-poverty intervention path $[\mathrm{J}]$. Proceedings of Shanghai Jiao Tong University (Philosophy and Social Sciences), 2020, 28(06): 9-15+58.

[4] Liu Wei, Wang Can, Zhao Xiaojun, et al. Income Distribution Gap in China: Current Situation, Reasons and Countermeasures Research [J]. Social Sciences Digest, 2019 (1): 45-47.
[5] Zhao Jinchun. Trade liberalization, labor market segmentation and poor growth [J]. World Economy Research, 2018 (11): 116-134.

[6] Yan Jirong, Wang Yu, Sheng. Theme Varito Ensuring Poverty and Development-China's Anti-Poverty Development and Prospect [J]. Journal of Nanjing Agricultural University (Social Sciences Edition), 2020, 20(04): 22-34.

\section{Author Profile}

Hui Li (1998- ), female, Zichuan District, Zibo City, Shandong Province, master's degree, Research direction: Agricultural Economy and Policy. 